Pesq. Vet. Bras. 30(5):423-427, maio 2010

\title{
Focal symmetrical encephalomalacia in sheep ${ }^{1}$
}

\author{
Luciano A. Pimentel2 ${ }^{2}$, Diego M. Oliveira², Glauco J.N. Galiza², Antônio F.M. \\ Dantas $^{2}$, Francisco Uzal ${ }^{3}$ and Franklin Riet-Correa ${ }^{*}$
}

\begin{abstract}
Pimentel L.A., Oliveira D.M., Galiza G.J.N., Dantas A.F.M., Uzal F. \& RietCorrea F. 2010. Focal symmetrical encephalomalacia in sheep. Pesquisa Veterinária Brasileira 30(5):423-427. Setor de Patologia Veterinária, Hospital Veterinário, CSTR, Campus de Patos, Universidade Federal de Campina Grande, Patos, PB 58700-000, Brazil. Email: franklin.riet@pq.cnpq.br

Focal symmetrical encephalomalacia (FSE) is the most prominent lesion seen in the chronic form of enterotoxemia by Clostridium perfringens type $\mathrm{D}$. This paper reports FSE in sheep in Brazil. Six deaths occurred within a seven days period in a flock of 70 , four to 30-month-old Santa Inês sheep in the state of Paraíba in the Brazilian semiarid. The flock was grazing a paddock of irrigated sprouting Cynodon dactylon (Tifton grass), and supplemented, ad libitum, with a concentrate of soybean, corn and wheat. Nervous signs included blindness and recumbence. A 19 month-old sheep was examined clinically and necropsied after a clinical course of three days. Gross lesions were herniation of the cerebellar vermis and multifocal, bilateral, symmetric brownish areas in the internal capsule, thalamus and cerebellar peduncles. Histologic lesions were multifocal, bilateral malacia with some neutrophils, swelling of blood vessels endothelium, perivascular edema, and hemorrhages. The flock was vaccinated, before the outbreak, with only one dose of Clostridium perfringens type $D$ vaccine. Two factors are suggested to be important for the occurrence of the disease: insufficient immunity due to the incorrect vaccination; and high nutritional levels by the supplementation with highly fermentable carbohydrates.
\end{abstract}

INDEX TERMS: Clostridium perfringens type D, epsilon toxin, enterotoxemia, malacia.

RESUMO.- [Encefalomalacia focal simétrica em ovino.] Encefalomalacia focal simétrica (EFS) é a lesão mais proeminente vista nas formas subaguda ou crônica da enterotoxemia por Clostridium perfringens tipo D. Este trabalho relata EFS em ovinos no semiárido do estado da Paraíba. Seis ovinos morreram, em um período de sete dias, dentro de um rebanho de 70 animais, da raça Santa Inês, entre 4-30 meses de idade, que pastavam em piquete de Cynodon dactylon (capim Tifton), que estava rebrotando. Os ovinos eram suplementados com um concentrado de soja, trigo e milho. Os sinais nervosos incluíam cegueira e decúbito lateral. Um ovino de 19 meses de idade foi examinado clinicamente e necropsiado, depois de

1 Received on December 17, 2009.

Accepted for publication on December 29, 2009.

${ }^{2}$ Hospital Veterinário, CSTR, Universidade Federal de Campina Grande (UFCG), Campus de Patos, 58700-000 Patos, PB, Brazil. *Corresponding author: franklin.riet@pq.cnpq.br

${ }^{3}$ California Animal Health and Food Safety, School of Veterinary Medicine University of California, Davis 105 W Central Ave, San Bernardino, CA 92408, USA. um curso clínico de 3 dias. Macroscopicamente foram observadas herniação do cerebelo e áreas acastanhadas, multifocais, simétricas e bilaterais na cápsula interna, tálamo e pedúnculo cerebelar. Histologicamente observou-se malacia, bilateral e simétrica, com alguns neutrófilos, tumefação das células endoteliais dos vasos sanguíneos, edema perivascular e hemorragia. O rebanho foi vacinado, antes do surto, com uma única dose de vacina para Clostridium perfringens tipo D. Dois fatores são sugestivos quanto a importância da ocorrência da enfermidade: imunidade insuficiente devida à vacinação incorreta; e altos níveis nutricionais da suplementação com carboidratos altamente fermentáveis.

TERMOS DE INDEXAÇÃO: Clostridium perfringens tipo D, toxina épsilon, enterotoxemia, malacia.

\section{INTRODUCTION}

Enterotoxemia is a disease of sheep and goats caused by Clostridium perfringens type D (McDonel 1980, Niilo 1980, Uzal \& Songer 2008) a bacterium that can be found as a normal inhabitant of the intestine in a small number of healthy 
animals (McDonel 1980, Niilo 1980). Alterations in the intestinal environment caused by sudden changes in diet, mainly in animals ingesting highly fermentable carbohydrates are associated with proliferation of $C$. perfringens type $D$ and production of epsilon prototoxin, which is then activated by intestinal trypsine and other proteases. Epsilon toxin is responsible for the clinical and pathologic findings of the disease in sheep (McDonel 1980, Niilo 1980, Uzal \& Kelly 1997, Uzal \& Songer 2008). In this species, the disease is most frequently acute or sub acute and both forms are characterized by perivascular proteinaceous edema in the brain (Uzal \& Songer 2008, Uzal et al. 2008). A chronic form of enterotoxemia occurs sporadically in lambs and, less commonly in older sheep. This form is mostly characterized by the development of focal symmetric encephalomalacia (FSE), affecting mainly the internal capsule, mesensephalon, thalamus, and cerebellar peduncles (Hartley 1956, Gay et al. 1975, Brown et al. 2007, Riet-Correa et al. 2007, Zachary 2007, Uzal \& Songer 2008). FSE has also been described as a spontaneous lesion in cattle, but to date the etiology has not been definitely established and no casual relationship has been established between this condition and $C$. perfringens epsilon toxin (Buxton et al. 1981). However, recently FSE was experimentally produced in cattle inoculated intraduodenally with C. perfringens type D (Facury Filho et al. 2009), which suggests that the spontaneous cases of this condition previously described in cattle (Buxton et al. 1981) are indeed, produced by $C$. perfringens type D. FSE is not a usual feature of goat enterotoxemia, although this lesion has also recently been reported for the first time in goats (Oliveira et al. 2010).

FSE of sheep has been reported in different regions of the world (Hartley 1956, Barlow 1958, Niilo 1980, Brown et al. 2007). In Brazil, FSE has been reported in Rio Grande do Sul (Riet-Correa 2007), Paraíba (Guedes et al. 2007) and Brasília (Castro 2008), but detailed descriptions of the disease and lesions have not been published. This paper reports an outbreak of $C$. perfringens type $D$ enterotoxemia with characteristic FSE lesions in sheep in the state of Paraíba, Northeastern Brazil.

\section{MATERIALS AND METHODS}

An outbreak of diarrhea followed by death occurred in May 2008 , during the rainy period, in a farm in the municipality of São Domingos, state of Paraíba, in a flock of 70 , four to 30 month-old hair, Santa Inês sheep. The flock was grazing during most of the day a native pasture, but during one hour per day it had also access to a one hectare irrigated paddock of sprouting Cynodon dactylon (Tifton grass), which had been cut two weeks before the onset of the disease. A concentrate ration including soybean, wheat and corn bran was also feed ad libitum at the end of the day. The farmer informed that five, 19 to 30-monthold sheep, were found dead 24 to 48 hours after a bout of diarrhea. The five animals died in a period of seven days. The sheep had arrived recently to the farm and were vaccinated, 15 days before the beginning of the outbreak, against enterotoxemia type $\mathrm{D}$ with a commercial vaccine.
A 19-month-old sheep that had been observed for one day at the farm showing uncoordinated gait and rising difficulties, followed by diarrhea and lateral recumbence, was submitted for diagnostic work up to the Veterinary Hospital of the Federal University of Campina Grande, in the city of Patos, state of Paraíba. The animal was examined clinically and immediately after spontaneous death it was necropsied. Samples of intestine, fore stomachs, abomasum, mesenteric lymph nodes, adrenal, spleen, liver, heart, lung, trigeminal ganglion and pituitary gland were fixed in buffered $10 \%$

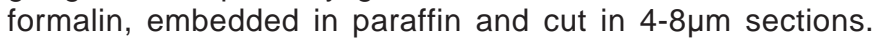
The whole brain and spinal cord were also fixed in $10 \%$ buffered formalin and transverse sections of the cervical, thoracic and lumbar spinal cord, medulla oblongata, pons, rostral and caudal colliculi, thalamus, corpus striatum, cortex, cerebellar peduncles and cerebellum were examined histologically. All tissues were stained with hematoxylin and eosin. Selected sections of the CNS were stained with PAS and luxol fast blue.

\section{RESULTS}

On clinical examination at the hospital the submitted sheep showed two ruminal movements in five minutes, while heart rate was 16 , respiratory rate was 24 and rectal temperature was $39.9^{\circ} \mathrm{C}$. Other clinical signs included apathy, congested apparent mucosas, lateral recumbence, nystagmus, strabismus, decreased menace and pupillary consensual reflexes, groaning, decreased sensibility of the face, and pedaling movements. The next day, the sheep also showed decreased tongue tonus, mandible trismus, and decreased anal reflex. The sheep was treated unsuccessfully with $10 \mathrm{mg} / \mathrm{kg}$ of IM thiamine and $0.2 \mathrm{mg} / \mathrm{kg}$ of IV dexamethasone, at 12 hours interval during two days, and it died after a total clinical course of three days.

At necropsy the carcass was in good nutritional condition, with adequate amount of fat reserves, well fleshed and in fresh post-mortem condition. The cerebellar vermis was herniated through the foramen magnum (Fig.1A,B). Multifocal, bilateral, brownish, $0.1-1.0 \mathrm{~cm}$ diameter areas were observed in the internal capsule, dorso-lateral of the thalamus, mesencephalon and cerebellar peduncles (Fig.1C,D). Several small cavities, softening of the tissue with gelatinous aspect, and occasionally multiple red small spots were also observed in those areas. No other significant gross abnormalities were observed in the rest of the carcass.

On histological examination, brain lesions were present only in those areas where gross lesions had been observed and consisted of malacia characterized by pallor and rarefaction of the neuropil with necrosis of glial cells (Fig.2A) and neurons, and the presence of swollen axons (spheroids). Occasionally, perivascular proteinaceous edema and hemorrhages were observed, and the vascular endothelium was swollen (Fig.2B). This edema was observed surrounding small to medium size arterioles and venules. Histological lesions outside the CNS included lung congestion and presence of hyaline casts in renal tubules. No significant histological lesions were observed in any of the other organs examined. 

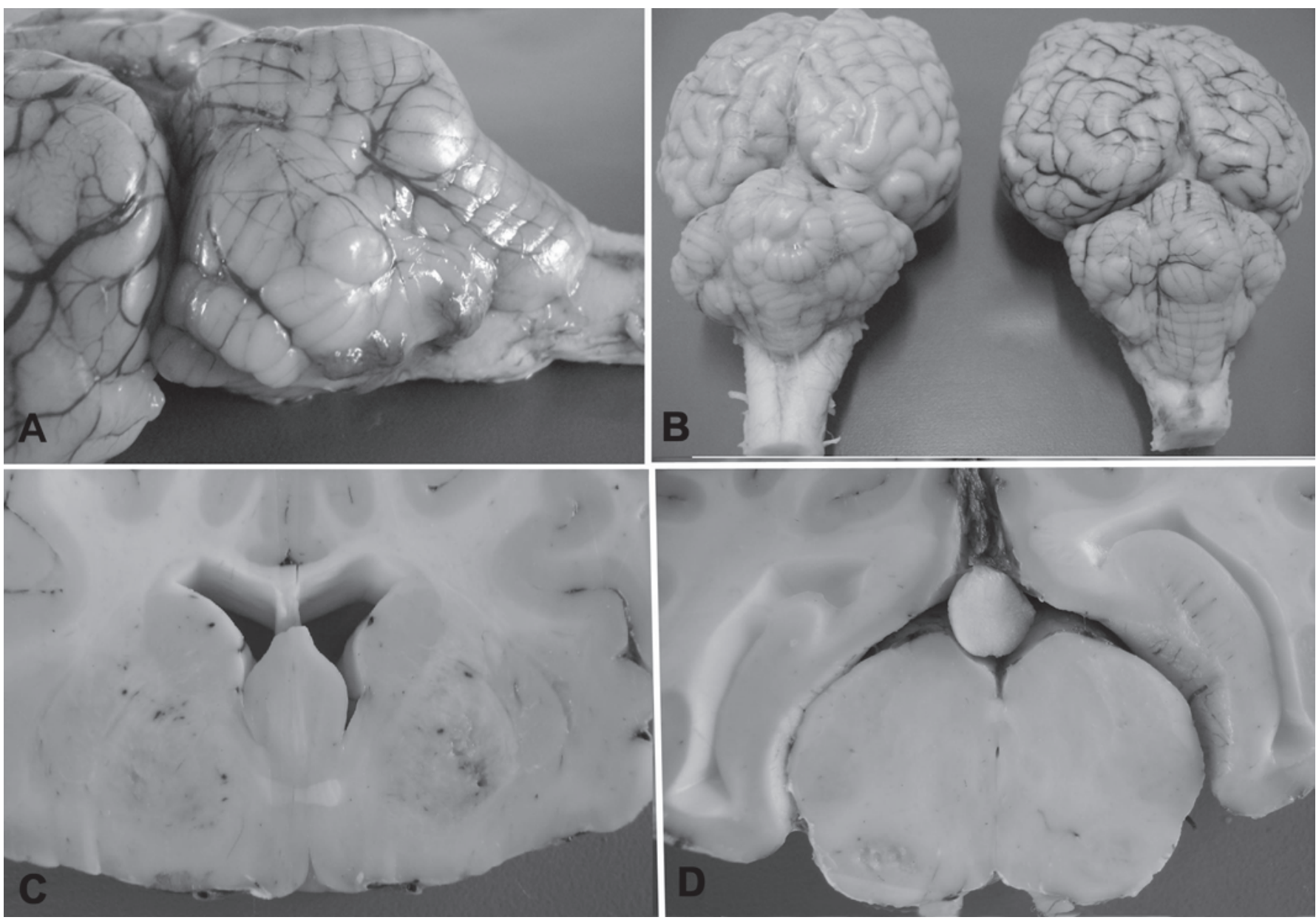

Fig.1. Focal symmetrical encephalomalacia in sheep. (A) Cerebellar herniation. (B) The herniated cerebellum, at right, is compared with a cerebellum from a control sheep. (C) Internal capsule and (D) mesencephalon with symmetric malacic foci.
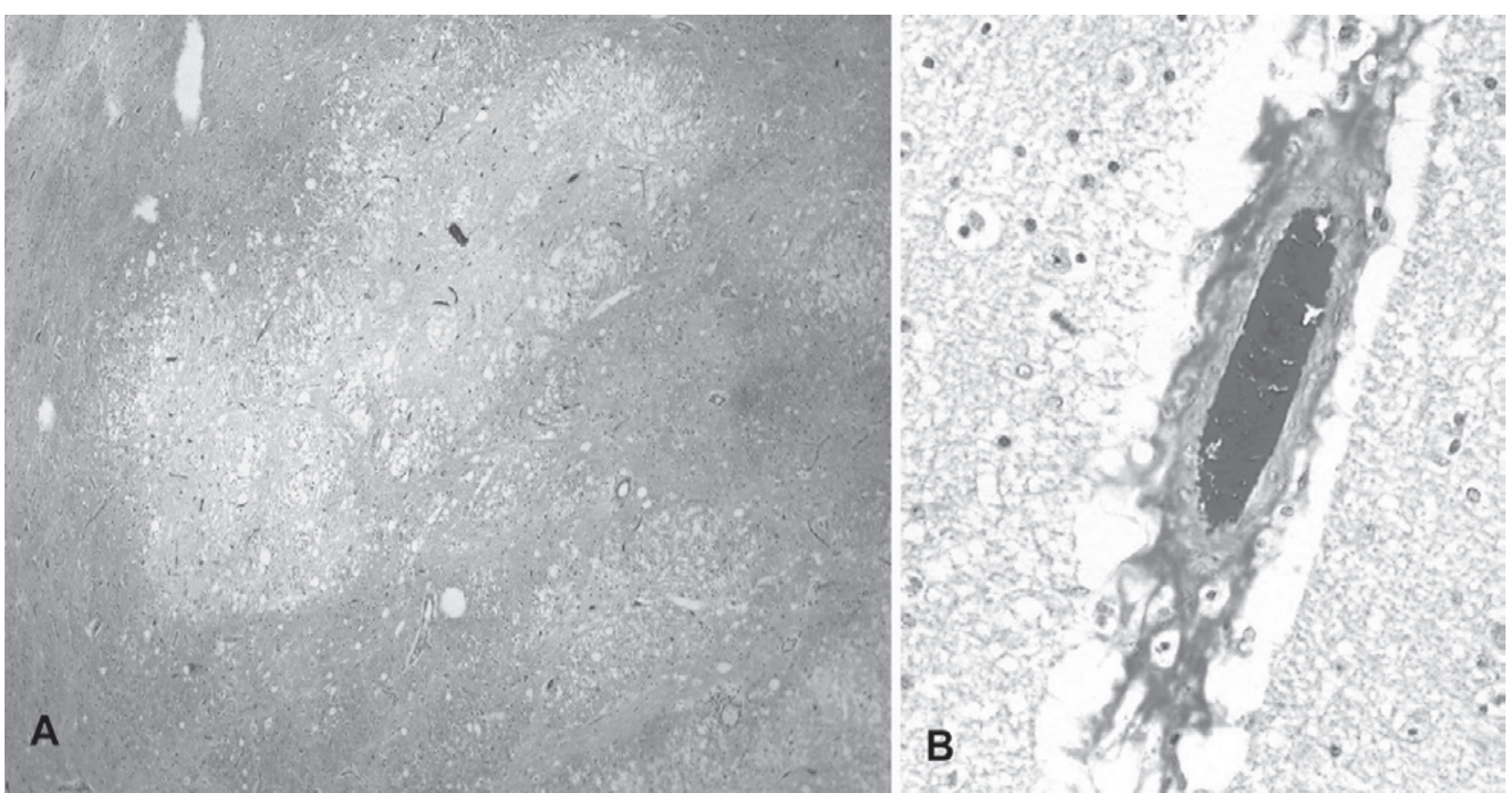

Fig.2. Focal symmetrical encephalomalacia in sheep. (A) Multifocal areas of necrosis are observed in the internal capsule. HE, obj.10x. (B) Perivascular edema in the thalamus HE, obj.20x. 


\section{DISCUSSION}

This paper reports an apparent outbreak of type D enterotoxemia with focal symmetric encephalomalacia (FSE) in sheep in Brazil. The disease was diagnosed based on the presence of FSE which is considered pathognomonic for type D enterotoxemia in sheep (Hartley 1956, Gay et al. 1975, Buxton \& Morgan 1976, Uzal \& Songer 2008).

FSE has been occasionally reported in different countries (Hartley 1956, Barlow 1958, Gay et al 1975, Sattler et al. 1998, Hazlett \& Reid 2002). In the Brazilian semiarid region enterotoxemia and FSE are seldom reported; between January 2000 and August 2009 the Veterinary Hospital in Patos reported three outbreaks of enterotoxemia, of which FSE was seen in only one of them, out of a total of 414 sheep cases investigated during that period.

The owner of the sheep in the case reported here mentioned that five sheep had shown diarrhea, being found dead the following day. However, because only one of these animals was submitted to our laboratory, it is difficult to know if the other sheep also died of enterotoxemia and/or if they presented FSE. Diarrhea is not usually observed in cases of enterotoxemia so it is possible that these sheep died of causes different from enterotoxemia.

FSE is an uncommon manifestation of enterotoxemia in sheep. The most likely reason for this is that development of FSE takes time (usually a minimum of $48 \mathrm{hrs}$ ) and most animals suffering from enterotoxemia die before this. FSE has been associated with low concentrations of epsilon toxin in the gut or with partially immunized sheep (Summers et al. 1995), which might facilitate longer survival of affected animals. Low epsilon toxin concentrations in the intestine can occur in animals that carry small numbers of $C$. perfringens type $D$ in the gut. Constant or frequent absorption of small amounts of epsilon toxin from the gut and/or improper vaccination can induce some degree of immunity. This low level of immunity, although not enough to prevent clinical disease, may facilitate survival of the affected animals for periods long enough for development of FSE. In the outbreak reported here the flock had received only one dose of $C$. perfringens type $D$ vaccine. Protective antibody levels to epsilon toxin are achieved only with 2 doses of vaccine, 4 to 6 weeks apart. It is therefore most likely that the vaccination induced low antitoxin serum concentration, which protected against the acute, but not the chronic form of enterotoxemia. In addition, in Brazil an evaluation of type $D$ enterotoxemia vaccines showed that only two out of six commercial vaccines induced neutralizing antibodies to the epsilon and beta toxins in rabbits and calves (Lobato et al. 2000).

Another factor associated with the outbreak reported here was the high nutritional level due to the good pastures during the rainy period together with supplementation with grains and byproducts containing highly fermentable carbohydrates, which are well known risk factors for the occurrence of enterotoxemia (Gay et al. 1975, Sattler et al. 1998, Hazlett \& Reid 2002, Radostits et al. 2007, Zachary 2007).
A definitive diagnosis of the acute or sub-acute forms of enterorotoxemia can be achieved by the determination of the presence of epsilon toxin in the intestine and/or by the presence of perivascular proteinaceous edema edema in the brain; while the presence of large amounts of Grampositive rods in gut smears and glycosuria are suggestive of the disease. The diagnosis of chronic cases of enterotoxemia is achieved mostly only by the observation of gross and histologic lesions of FSE located mainly in the internal capsule, thalamus, mesencephalon and cerebellar peduncles. However, epsilon toxin is usually not detected in the gut in chronic cases of the disease. Therefore, the presence of epsilon toxin was not investigated in this case.

The cerebellar herniation, observed in the sheep in this report, has been reported as a characteristic lesion of subacute and chronic enterotoxemia in sheep (Buxton \& Morgan 1976, Uzal \& Songer 2008, Uzal et al. 2008) and was also observed in sub-acute experimental cases of $C$. perfringens type D infection in mice (Fernandez-Miyakawa et al. 2007).

Enterotoxemia has to be differentiated from other disease of the nervous system in sheep, including polioencephalomalacia, listeriosis, rabies and pregnancy toxemia. In this case, all the diseases mentioned were ruled out based on the absence of histological findings characteristic of each of them and on the presence of lesions of FSE.

When a diagnosis of type $D$ enterotoxemia has been established, the flock has to be vaccinated immediately and nutritional measures have to be adopted until the establishment of good immunity. For the prophylaxis, lambs born from non vaccinated sheep have to be vaccinated at 1-2 months of age, and lambs born from vaccinated ewes should be vaccinated at 2-3 months. A booster should be administered 4 to 6 weeks after the first vaccination. In sheep an annual booster 2 to 4 weeks before lambing is recommended (Radostits et al. 2007, Riet-Correa et al. 2007, Uzal et al. 2008).

Acknowledgements.- To CNPq (Conselho Nacional de Desenvolvimento Científico e Tecnológico) for the scholarship given to the first author.

\section{REFERENCES}

Barlow R. 1958. Focal symmetrical encephalomalacia in lambs. Vet. Rec. 70:884.

Brown C.C., Baker D.C. \& Barker L.K. 2007. The alimentary system, p.1-296. In: Maxie M.G. (Ed.), Jubb, Kennedy \& Palmer's Pathology of Domestic Animals. Vol.2. $5^{\text {th }}$ ed. Saunders Elsevier, Edinburgh.

Buxton D., Macleod N.S.M. \& Nicolson T.B. 1981. Focal symmetrical encephalomalacia in young cattle. Vet. Rec. 108:459.

Buxton D. \& Morgan K.T. 1976. Studies of lesions produced in the brains of colostrum deprived lambs by Clostridium welchii $(\mathrm{Cl}$. perfringens) type D toxin. J. Comp. Pathol. 86:435-447.

Castro M.B. 2008. Personal communication (School of Veterinary Medicine, University of Brasília).

Colodel E.M., Driemeier D., Schmitz M., Germer M., Nascimento R.A.P., Assis R.A., Lobato F.C.F. \& Uzal F.A. 2003. Enterotoxemia em caprinos no Rio Grande do Sul. Pesq. Vet. Bras. 23:173-178. 
Fernandez-Miyakawa M.E., Sayeed S., Fisher D.J., Poon R., Adams V., Rood J.I., McClane B.A., Saputo J. \& Uzal F.A. 2007. Development and application of an oral challenge mouse model for studying Clostridium perfringens type D. Infect. Immun. 75:4282-4288.

Facury Filho E.J., Carvalho A.U., Assis R.A., Lobato F.F., Rachid M.A., Carvalho A.A., Ferreira P.M., Nascimento R.A., Fernandes A.A., Vidal J.E. \& Uzal F.A. 2009. Clinicopathologic features of experimental Clostridium perfringens type $D$ enterotoxemia in cattle. Vet. Pathol. 46:1213-1220.

Gay C.C., Blood D.C. \& Wilkinson J.S. 1975. Clinical observations of sheep with focal symmetrical encephalomalacia. Aust. Vet. J. 51:266269.

Guedes K.M.R., Riet-Correa F., Dantas A.F.M., Simões S.V.D., Miranda Neto E.G., Nobre V.M.T. \& Medeiros R.M.T. 2007. Doenças do sistema nervoso central em caprinos e ovinos no semi-árido. Pesq. Vet. Bras. 27:29-38.

Hartley W.J. 1956. A focal symmetrical encephalomalacia of lambs. N. Z. Vet. J. 4:129-135.

Hazlett M. \& Reid S. 2002. Focal symmetrical encephalomalacia in two lambs. AHL Newsletter 6:30.

Lobato F.C.F., Moro E., Umehara O., Assis R.A., Martins N.E. \& Gonçalves L.C.B. 2000. Avaliação da resposta de antitoxinas beta e épsilon de Clostridium perfringens induzidas em bovinos e coelhos por seis vacinas comerciais no Brasil. Arq. Bras. Med. Vet. Zootec. 52:313-318.

McDonel J.L. 1980. Clostridium perfringens (type A, B, C, D, E). Pharmacol. Ther. 10:617-655.

Niilo L. 1980. Clostridium perfringens in animal disease: A review of current knowledge. Can. Vet. J. 21:141-148.
Oliveira D.M., Pimentel L.A., Pessoa A.F., Dantas A.F.M., Uzal F. \& Riet-Correa F. 2010. Focal symmetrical encephalomalacia in a goat. J. Vet. Diag. Invest. 22(5):in press.

Radostits O.M., Gay C.C., Hinchcliff K.W. \& Constable P.D. 2007. Veterinary Medicine: A textbook of the diseases of cattle, horses, sheep, pigs, and goats. $10^{\text {th }}$ ed. Saunders Elsevier, Edinburgh.

Riet-Correa F. 2007. Enterotoxemia e necrose simétrica focal, p.288293. In: Riet-Correa F., Schild A.L., Lemos R.A.A. \& Borges J.R.J. (Eds), Doenças de Ruminantes e Eqüinos. Vol.1. $3^{\underline{a}}$ ed. Pallotti, Santa Maria, RS.

Sattler N., Fecteau G., Desnoyers M., Quesnel A. \& Chénier S. 1998. Focal symmetric encephalomalacia in a 6-month-old dorset sheep. Can. Vet. J. 39:434-437.

Summers B.A., Cummings J.F. \& de Lahunta A. 1995. Veterinary Neuropathology. Mosby, St Louis, p.258-161.

Uzal F.A., Glastonbury J.R.W., Kelly W.R. \& Thomas R. 1997. Caprine enterotoxaemia associated with cerebral microangiopathy. Vet. Rec. 141:224-226.

Uzal F.A. \& Kelly W.R. 1997. Effects of the intravenous administration of Clostridium perfringens type $\mathrm{D}$ epsilon toxin on young goats and lambs. J. Comp. Pathol. 116:63-71.

Uzal F.A., Porcel J.O.M. \& Arenas J.M.C. 2008. Enterotoxemia ovina y caprina. Cuadernos de Campo, Ivomec. 157p.

Uzal F.A. \& Songer J.G. 2008. Diagnosis of Clostridium perfringens intestinal infections in sheep and goats. J. Vet. Diagn. Invest. 20:253265.

Zachary J.F. 2007. Nervous System, p.833-971. In: McGavin M.D. \& Zachary J.F. (Eds), Pathologic Basis of Veterinary Disease. $4^{\text {th }}$ ed. Mosby Elsevier, St Louis. 